\title{
Middle ear neuroendocrine tumor
}

INSERM

\section{Source}

INSERM. (1999). Orphanet: an online rare disease and orphan drug data base. Middle ear neuroendocrine tumor. ORPHA:100084

Middle ear neuroendocrine tumor is a rare, otorhinolaryng ologic tumor characterized by a mixed glandular and non-glandular histological features and positive immunostaining for pancytokeratin, vimentin, synaptophysin and islet-1 protein. Common signs and symptoms are hearing loss, mass, pain, discharge, equilibrium disturbances, tinnitus and nerve paralysis. 